\title{
Testosterone enhances lipopolysaccharide-induced interleukin-6 and macrophage chemotactic protein-1 expression by activating the extracellular signal-regulated kinase 1/2/nuclear factor- $\kappa B$ signalling pathways in 3T3-L1 adipocytes
}

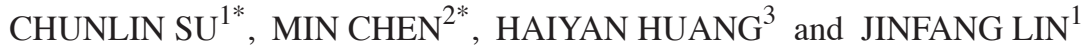 \\ ${ }^{1}$ Department of Gynecology, Shanghai Obstetrics and Gynecology Hospital Affiliated to Fudan University, Shanghai 200011; \\ ${ }^{2}$ Department of Reproductive Medicine Center, Shuguang Hospital Affiliated to Shanghai University of Traditional Chinese \\ Medicine, Shanghai 201203; ${ }^{3}$ Key Laboratory of Molecular Medicine Ministry of Education, \\ Shanghai Medical University Affliated to Fudan University, Shanghai 200011, P.R. China
}

Received February 28, 2014; Accepted December 2, 2014

DOI: $10.3892 / \mathrm{mmr} .2015 .3401$

\begin{abstract}
Low-grade chronic inflammation is commonly found in patients with polycystic ovary syndrome (PCOS) who exhibit hyperandrogenism or hyperandrogenemia. Clinical studies have shown that hyperandrogenemia is closely correlated with low-grade chronic inflammation. However, the mechanism underlying this correlation remains unclear. Recent studies have suggested that adipocytes increase the production of proinflammatory mediators such as interleukin-6 (IL-6) and macrophage chemotactic protein-1 (MCP-1) when the inflammatory signal transduction cascade system is activated by external stimuli. The present study aimed to evaluate the effects of testosterone on the innate signalling and expression of proinflammatory mediators in 3T3-L1 adipocytes, which were or were not induced by lipopolysaccharide (LPS). The effects of testosterone on the expression of proinflammatory mediators, nuclear factor- $\kappa \mathrm{B}(\mathrm{NF}-\kappa \mathrm{B})$, and extracellular signal-regulated kinase 1/2 (ERK1/2) signalling pathways were investigated using an enzyme-linked immunosorbent assay, reverse transcriptase-polymerase chain reaction, western blot analysis and an electrophoresis mobility shift assay. Testosterone induces IL-6 and MCP-1, and enhances LPS-induction of IL-6 and MCP-1. However, the effects are not simply additive, testosterone significantly enhanced the
\end{abstract}

Correspondence to: Dr Jinfang Lin, Department of Gynecology, Shanghai Obstetrics and Gynecology Hospital Affiliated to Fudan University, 128 Shenyang Road, Shanghai 200011, P.R. China

E-mail: jinfanglincn@yeah.net

${ }^{*}$ Contributed equally

Key words: testosterone, interleukin-6, macrophage chemotactic protein-1, extracellular signal-regulated kinase, nuclear factor- $\kappa \mathrm{B}$, 3T3-L1 adipocytes effects of LPS-induced inflammation factors. Testosterone induces the phosphorylation of ERK $1 / 2$ and NF- $\kappa \mathrm{B}$. The effect of testosterone on the expression of IL- 6 and MCP-1 is inhibited by PD98059, an ERK1/2 inhibitor, and PDTC, an NF- $\kappa \mathrm{B}$ inhibitor. The results indicate that testosterone enhances LPS-induced IL- 6 and MCP-1 expression by activating the ERK1/2/NF- $\kappa$ B signalling pathways in 3T3-L1 adipocytes.

\section{Introduction}

Polycystic ovary syndrome (PCOS) is estimated to affect 5-7\% of premenopausal females and is associated with a significant risk of developing type two diabetes (T2D), independently of obesity (1). PCOS is characterized by a hyperandrogenic state, and exposure to exogenous testosterone in vivo has been associated with low-grade chronic inflammation in rats and human females. Low-grade chronic inflammation has an important function in the development of insulin resistance, as it triggers the metabolic syndrome $(2,3)$. The risk of developing the metabolic syndrome in adolescent females with PCOS is correlated with increasing concentrations of bioavailable testosterone, an effect which is independent of obesity (4). However, the mechanism by which hyperandrogenism results in the development of low-grade chronic inflammation remains undefined.

Studies have shown that in patients with PCOS, a number of proinflammatory factors, such as interleukin-6 (IL-6), macrophage chemotactic protein-1 (MCP-1) and tumor necrosis factor- $\alpha$ (TNF- $\alpha$ ), are positively correlated with serum testosterone concentration. An association between low-grade chronic inflammation and testosterone levels has been demonstrated by intervention studies using simvastatin (5) and flutamide (6) in PCOS. When mononuclear cells from the peripheral blood of PCOS patients were exposed to high-sugar conditions in vitro, the concentration of TNF- $\alpha$ in the supernatant was positively correlated with the serum testosterone level. We hypothesised that excess androgen in PCOS may be a key factor in the development of low-grade chronic inflammation (7). 
Adipocytes have a crucial function in low-grade chronic inflammation as these cells are sources of cytokines (IL-6, and MCP-1) that are secreted during the activation of certain signalling cascades, which are involved in insulin resistance (8). Current research also suggests that low-grade chronic inflammation is initiated and controlled by adipose tissue as weight loss is able to significantly alleviate low-grade chronic inflammation $(9,10)$. Adipocytes are an important component of adipose tissue and are classic insulin target cells. These cells have a function in the storage and maintenance of energy, and in the balance of glucose and lipid metabolism. In addition, fat cells, in a similar manner to immune cells, activate complement components, such as $\mathrm{C} 3$ and produce proinflammatory mediators and chemokines, such as IL-6 and MCP-1, thus triggering inflammation signaling pathways, including p38 mitogen-activated protein kinase (p38-MAPK), extracellular signal-regulated kinase (ERK), inhibitor of nuclear factor- $\kappa \mathrm{B}(\mathrm{IKK}-\beta / \mathrm{NF}-\kappa \mathrm{B})$ and protein kinase $\theta / \delta$ $(\mathrm{PKC} \theta / \delta)$, and promoting macrophage infiltration. In addition, adipocytes are target cells for androgen.

IL-6 is a multipotent cytokine, which is an important molecule in inflammatory reactions. Furthermore, $30 \%$ of IL-6 is produced by adipocytes (11). IL-6 promotes insulin resistance (IR) by inducing the expression of cytokine signalling suppressor factor (SOCS), thus inhibiting the phosphorylation of the insulin receptor substrate 1 (IRS-1) tyrosine residue, which blocks insulin signal transduction. IL-6 is also able to inhibit glucose transporter-4 (GLUT4) expression (12), resulting in IR. The production of IL- 6 is closely correlated to the activation of $\mathrm{NF}-\kappa \mathrm{B}(13)$.

Chemoattractant proteins, or chemokines, are small proteins that activate (chemoattract) leukocytes during low-grade chronic inflammation. MCP-1, secreted as a chemokine by adipocytes, increases the flux of monocytes into adipose tissue. Measures of chemokine levels are closely associated with insulin resistance, which is in accordance with other studies $(14,15)$. MCP-1 is able to induce insulin resistance through a number of pathways. It is known to promote the production of free fatty acids (FFAs) (16). In addition, MCP-1 promotes monocyte/macrophage activation and aggregation $(17,18)$, resulting in the development of adipose tissue inflammation.

$\mathrm{NF}-\kappa \mathrm{B}$ has been implicated in low-grade chronic inflammation and in acute inflammation. $N F-\kappa B$ is a family of homodimeric or heterodimeric transcription factors, which includes p50, p52, p65, relb and c-rel. Free NF- $\mathrm{B}$ translocates to the nucleus and binds to a common DNA sequence motif, which includes the b site, in a broad spectrum of genes, including inflammatory cytokines and chemokines. The ERK1/2 pathways are also known to activate NF- $\mathrm{B}$ (19). Thus, the production of proinflammatory mediators, including inflammatory cytokines and chemokines, is controlled by the activity of transcription factors, such as NF- $\mathrm{B}$ and ERK1/2. A number of studies have implicated chronic activation of the proinflammatory transcription factor, $\mathrm{NF}-\kappa \mathrm{B}$, as the primary pathway, of all the signaling pathways, that link inflammation with obesity and T2D (20,21). Studies have reported that in different types of cells, androgen selectively activates p38MAPK (22), NF- $\mathrm{BB}$ (23) and ERK1/2 (24).

Therefore, in the present study, the impact of testosterone on the expression of IL- 6 and MCP-1, as well as on the NF- $\kappa$ B and ERK1/2 signalling pathways, was investigated in 3T3-L1 adipocytes.

\section{Materials and methods}

Cell culture. 3T3-L1 preadipocytes (American Type Culture Collection, Manassas, VA, USA) were maintained in Dulbecco's modified Eagle's medium (DMEM; Nacalai Tesque, Kyoto, Japan), containing 10\% fetal bovine serum (FBS; Sanko Junyaku, Eidia Cp. Tokyo, Japan) and antibiotics. The pre-adipocytes were then incubated at $37^{\circ} \mathrm{C}$ for $48 \mathrm{~h}$ in a humidified atmosphere of $10 \% \mathrm{CO}_{2} / 95 \%$ air. The differentiation of 3T3-L1 pre-adipocytes from mature adipocytes was induced using insulin, dexamethasone and 3-isobutyl-1-methlyxanthine, as described previously (25), which were all purchased from Sigma-Aldrich (St. Louis, MO, USA). The mature 3T3-L1 adipocytes were used at day 8 , following the induction of differentiation. Hypertrophied 3T3-L1 cells with larger lipid droplets cultured up to day 10 were used. The medium was removed and changed for non-serum DMEM for $24 \mathrm{~h}$. The supernatant was collected for subsequent measurements.

Grouping. Matured 3T3-L1 adipocytes were grouped and treated as follows: 1, testosterone-only group, 3T3-L1 adipocytes were treated with testosterone (Sigma-Aldrich) at concentrations from $1 \mathrm{nmol} / 1$ to $10 \mu \mathrm{mol} / 1$ for $10 \mathrm{~min}, 30 \mathrm{~min}, 12 \mathrm{~h}, 24 \mathrm{~h}$ or $48 \mathrm{~h}$, and matured 3T3-L1 adipocytes without acted as a blank control group; 2, lipopolysaccharide (LPS) and testosterone group, LPS (Sigma-Aldrich) was dissolved in sterile, pyrogen-free phosphate-buffered saline (Double Helix, Shanghai, China), and the 3T3-L1 adipocytes were pre-treated with testosterone at concentrations ranging from $1 \mathrm{nmol} / 1$ to $10 \mu \mathrm{mol} / 1$ for $10 \mathrm{~min}, 30 \mathrm{~min}$ 12,24 and $48 \mathrm{~h}$, following which LPS $(1 \mu \mathrm{g} / \mathrm{ml})$ was added (26) for $6 \mathrm{~h}$, with 3T3-L1 adipocytes treated only with LPS as the control group, and a group without any treatment acted as a blank control. 3, PD98059 (ERK1/2 inhibitor; Sigma-Aldrich), LPS and testosterone group. PD98059 $(50 \mu \mathrm{mol} / \mathrm{l})$ pre-treatment for $2 \mathrm{~h}$, followed by $10 \mu \mathrm{mol} / \mathrm{l}$ testosterone treatment for $12 \mathrm{~h}$, then $1 \mu \mathrm{g} / \mathrm{ml}$ LPS treatment for $6 \mathrm{~h}$. 3T3-L1 adipocytes treated without PDT8059, LPS or testosterone as control groups, and a group without any treatment acting as a blank control. 4, PDTC (NF- $\kappa$ B inhibitor; Sigma-Aldrich), LPS and testosterone group. PDTC $(100 \mu \mathrm{mol} / \mathrm{l})$ pre-treatment for $2 \mathrm{~h}$, followed by $10 \mu \mathrm{mol} / 1$ testosterone treatment for $12 \mathrm{~h}$, then $1 \mu \mathrm{g} / \mathrm{ml}$ LPS treatment for 6 h. 3T3-L1 adipocytes treated without PDTC, LPS or testosterone as control groups, and a group without any treatment acted as a blank control.

Detecting IL-6 and MCP-1 concentrations. The supernatant of the cells treated as described above, was collected into a $1.5 \mathrm{ml}$ centrifuge tube, was centrifuged at 2,000 x $\mathrm{g}$ for $10 \mathrm{~min}$ and IL- 6 and MCP-1 concentrations were determined using a commercial mouse IL-6 and MCP-1 quantikine enzyme-linked immunosorbent assay kit, according to the manufacturer's instructions (R\&D Systems, Shanghai, China). Absorbance at $450 \mathrm{~nm}$ was measured and corrected using the $540 \mathrm{~nm}$ reading on a Benchmark microplate reader, Model 680 (Bio-Rad Laboratories, Hercules, CA, USA). Data were analysed using Microplate Manager III software (Bio-Rad Laboratories). 
A

The effects of testosterone on IL-6 in adipocytes

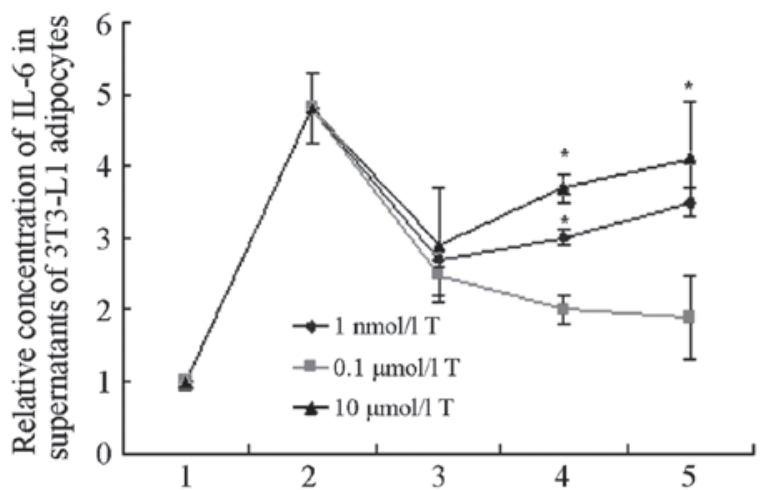

C

The effects of testosterone on IL-6 in 3T3-L1 adipocytes with LPS

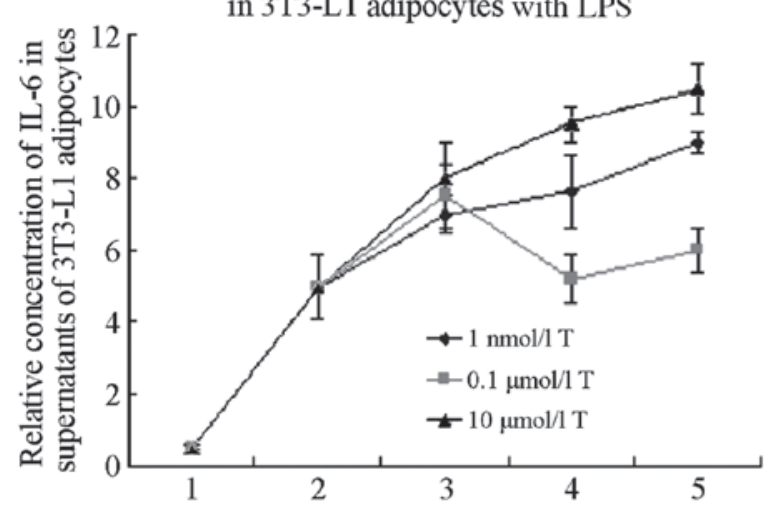

$\mathbf{E}$

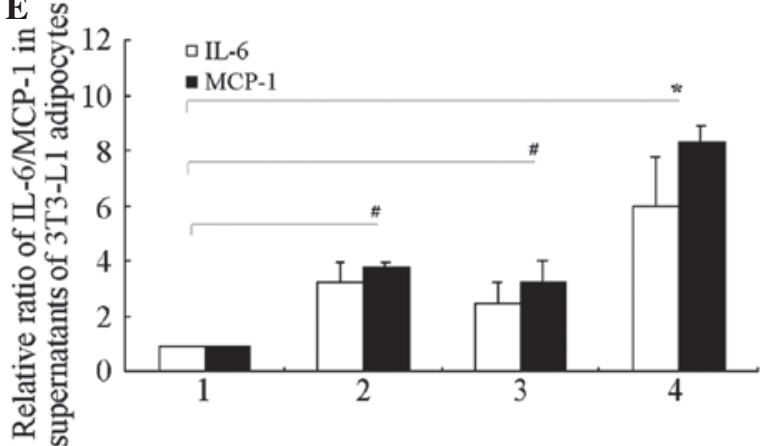

B

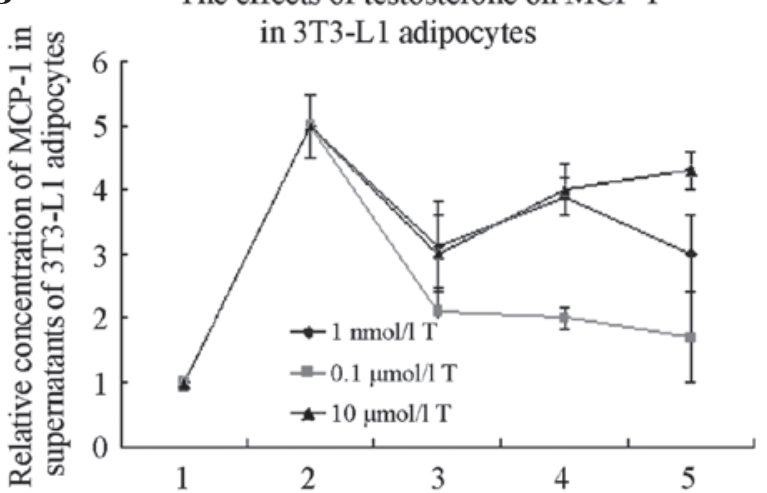

D
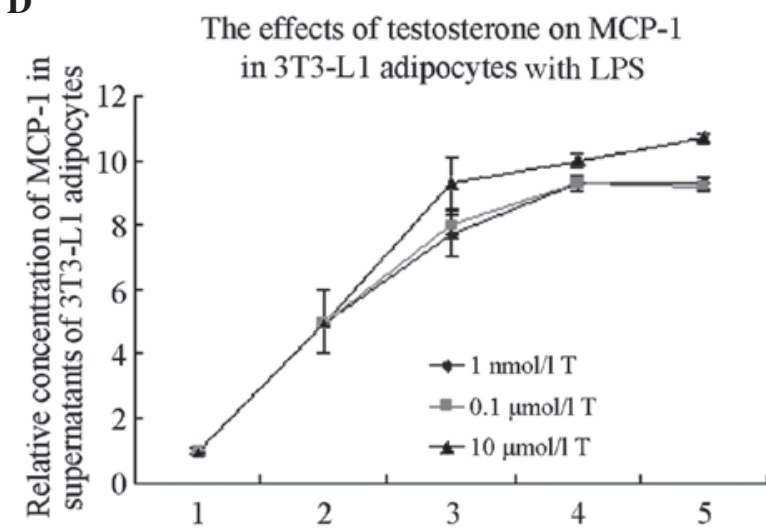

Figure 1. T increases the expression of LPS-induced inflammatory factors, IL-6 and MCP-1, in 3T3-L1 adipocytes, but not in a time- or dose-dependent manner. (A) Effects of $\mathrm{T}$ on the concentration of IL- 6 in supernatants of 3T3-L1 adipocytes. ${ }^{*} \mathrm{P}<0.05$ compared with controls. In groups with $10 \mu$ mol/1 $\mathrm{T}$ treatment for $24 \mathrm{~h}$, the concentration of IL-6 in the supernatants was higher than that in any other T-only-treated group ( $\mathrm{P}<0.05) .1$, controls; $2,1 \mu \mathrm{g} / \mathrm{ml} \mathrm{LPS}$ treatment for $6 \mathrm{~h} ; 3, \mathrm{~T}$ treatment for $12 \mathrm{~h} ; 4, \mathrm{~T}$ treatment for $24 \mathrm{~h}$; and 5, T treatment for $48 \mathrm{~h}$. (B) Effects of T on the concentration of MCP-1 in supernatants of 3T3-L1 adipocytes. In groups with $10 \mu \mathrm{mol} / 1 \mathrm{~T}$ treatment for $24 \mathrm{~h}$, the concentration of MCP-1 in the supernatants was higher than that in the other T-only-treated groups $(\mathrm{P}<0.05)$. 1, controls; $2,1 \mu \mathrm{g} / \mathrm{ml}$ LPS treatment for $6 \mathrm{~h} ; 3$, T treatment for $12 \mathrm{~h} ; 4, \mathrm{~T}$ treatment for $24 \mathrm{~h}$; and $5, \mathrm{~T}$ treatment for $48 \mathrm{~h}$. (C) Effects of T on the concentration of IL-6 in supernatants in 3T3-L1 adipocytes with LPS. In the groups with $10 \mu \mathrm{mol} / 1 \mathrm{~T}$ pre-treated for $24 \mathrm{~h}$ with LPS added, the concentration of IL-6 in the supernatants was greater than that of the other T-pre-treated groups $(\mathrm{P}<0.05) .1$, controls; $2,1 \mu \mathrm{g} / \mathrm{ml} \mathrm{LPS}$ treated $6 \mathrm{~h} ; 3$, T pre-treated $12 \mathrm{~h}$, then added $1 \mu \mathrm{g} / \mathrm{ml} \mathrm{LPS} \mathrm{treated} 6 \mathrm{~h} ; 4$, T pre-treated $24 \mathrm{~h}$, then added $1 \mu \mathrm{g} / \mathrm{ml} \mathrm{LPS} \mathrm{treated} 6 \mathrm{~h} ; 5$, T pre-treated $48 \mathrm{~h}$, then added $1 \mu \mathrm{g} / \mathrm{ml}$ LPS treated $6 \mathrm{~h}$. (D) Effects of T on the concentration of MCP-1 in supernatants in 3T3-L1 adipocytes with LPS. In groups with $10 \mu \mathrm{mol} / 1 \mathrm{~T}$ pre-treatment for $24 \mathrm{~h}$ with subsequent LPS, the concentration of MCP-1 in the supernatants was higher than that in the other T-pre-treated groups $(\mathrm{P}<0.05) .1$, controls; $2,1 \mu \mathrm{g} / \mathrm{ml} \mathrm{LPS} \mathrm{treatment} \mathrm{for} 6 \mathrm{~h}$; $3, \mathrm{~T}$ pre-treatment for $12 \mathrm{~h}$, with subsequent $1 \mu \mathrm{g} / \mathrm{ml} \mathrm{LPS} \mathrm{treatment} \mathrm{for} 6 \mathrm{~h} ; 4$, T pre-treatment for $24 \mathrm{~h}$, with subsequent $1 \mu \mathrm{g} / \mathrm{ml} \mathrm{LPS} \mathrm{treatment} \mathrm{for} 6 \mathrm{~h}$; and 5 , T pre-treatment for $48 \mathrm{~h}$, with subsequent $1 \mu \mathrm{g} / \mathrm{ml}$ LPS treatment for $6 \mathrm{~h}$. (E) Effects of T on the concentration of MCP-1 and IL-6 in supernatants of 3T3-L1 adipocytes with or without LPS ("P<0.01 and ${ }^{~} \mathrm{P}<0.05$ ). 1 , controls; $2,1 \mu \mathrm{g} / \mathrm{ml} \mathrm{LPS} \mathrm{treatment} \mathrm{for} 6 \mathrm{~h} ; 3,10 \mu \mathrm{mol} / 1 \mathrm{~T}$ treatment for $12 \mathrm{~h}$; and $4,10 \mu \mathrm{mol} / 1 \mathrm{~T}$ pre-treatment for $12 \mathrm{~h}$, with subsequent $1 \mu \mathrm{g} / \mathrm{ml}$ LPS treatment for $6 \mathrm{~h}$. T, Testosterone; LPS, lipopolysaccharide; IL-6, interleukin-6.

Detection of $N F-\kappa B$ (p65) transcription factor DNA binding activity. Cellular nuclear extracts were prepared using the NF- $\kappa B$ (p65) Transcription Factor Assay kit according to the manufacturer's instrucations (Abnova, Walnut, CA, USA). The protocol was as follows: Complete transcription factor binding assay buffer (CTFB) was prepared. CTFB $(90 \mu \mathrm{l})$ per sample well (or $80 \mu \mathrm{l}$ if adding competitor dsDNA or $100 \mu \mathrm{l}$ for the blank control) was added to the blank and non-specific binding wells. Competitor dsDNA (10 $\mu \mathrm{l})$ was then added to the appropriate wells. A positive control $(10 \mu \mathrm{l})$ was also added to the appropriate wells. Cellular nuclear extracts containing NF-кB $(10 \mu \mathrm{l})$ were also added to appropriate wells. The 


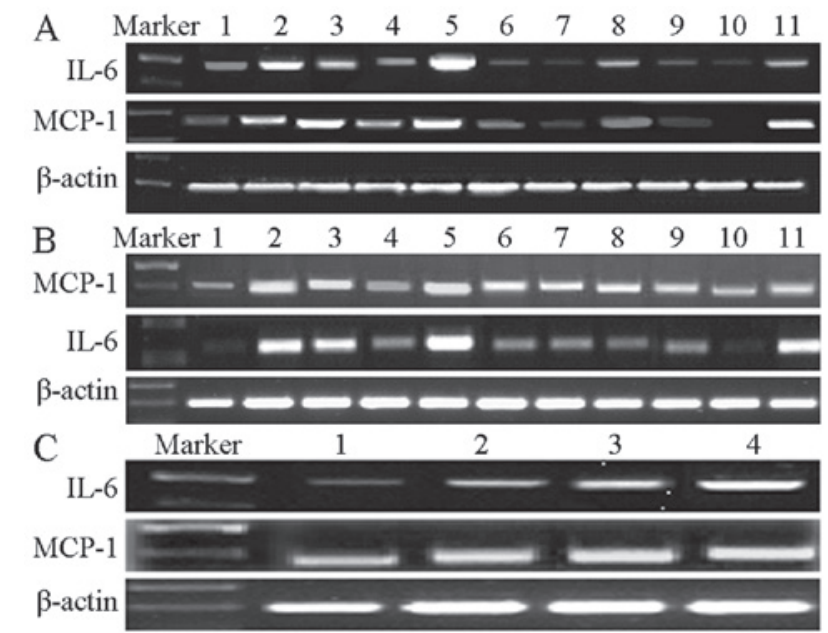

Figure 2. T increased the mRNA expression of LPS-induced inflammatory factors, IL-6 and MCP-1, in 3T3-L1 adipocytes. Total RNA was isolated, and IL-6 and MCP-1 expression was measured through reverse transcription polymerase chain reaction. Images shown are representative images from $\geq 3$ independent experiments. (A) T induced the mRNA expression of IL- 6 and MCP-1 in 3T3-L1 adipocytes compared with blank controls, in particular in the group with $10 \mu \mathrm{mol} / 1 \mathrm{~T}$ treatment for $12 \mathrm{~h}$. Lane 1, blank controls; lane 2 , LPS treatment for $6 \mathrm{~h}$; lane $3,1 \mathrm{nmol} / 1 \mathrm{~T}$ treatment for $12 \mathrm{~h}$; lane $4,0.1 \mu \mathrm{mol} / 1$ $\mathrm{T}$ treatment for $12 \mathrm{~h}$; lane 5, $10 \mu \mathrm{mol} / 1 \mathrm{~T}$ treatment for $12 \mathrm{~h}$; lane $6,1 \mathrm{nmol} / 1 \mathrm{~T}$ treatment for $24 \mathrm{~h}$; lane 7, $0.1 \mu \mathrm{mol} / 1 \mathrm{~T}$ treatment for $24 \mathrm{~h}$; lane $8,10 \mu \mathrm{mol} / 1 \mathrm{~T}$ treatment for $24 \mathrm{~h}$; lane $9,1 \mathrm{nmol} / 1 \mathrm{~T}$ treatment for $48 \mathrm{~h}$; lane $10,0.1 \mu \mathrm{mol} / 1 \mathrm{~T}$ treatment for $48 \mathrm{~h}$; and lane $11,10 \mu \mathrm{mol} / 1 \mathrm{~T}$ treatment for $48 \mathrm{~h}$. (B) T promoted LPS-induced IL-6 and MCP-1 mRNA expression in 3T3-L1 adipocytes compared with blank controls and the LPS-treated group, in particular in the group with $10 \mu \mathrm{mol} / 1 \mathrm{~T}$ pre-treatment for $12 \mathrm{~h}$. Lane 1, blank controls; lane 2 , LPS treatment for $6 \mathrm{~h}$. Lanes 3-11 T pre-treatments were followed with LPS treatment for $6 \mathrm{~h}$. Lane $3,1 \mathrm{nmol} / 1 \mathrm{~T}$ pre-treatment for $12 \mathrm{~h}$; lane $4,0.1 \mu \mathrm{mol} / 1$ T pre-treatment for $12 \mathrm{~h}$; lane $5,10 \mu \mathrm{mol} / 1 \mathrm{~T}$ pre-treatment for $12 \mathrm{~h}$; lane 6 , $1 \mathrm{nmol} / 1 \mathrm{~T}$ pre-treatment for $24 \mathrm{~h}$; lane $7,0.1 \mu \mathrm{mol} / 1 \mathrm{~T}$ pre-treatment for $24 \mathrm{~h}$; lane $8,10 \mu \mathrm{mol} / 1 \mathrm{~T}$ pre-treatment for $24 \mathrm{~h}$; lane $9,1 \mathrm{nmol} / 1 \mathrm{~T}$ treatment for $48 \mathrm{~h}$; lane 10,0.1 $\mu \mathrm{mol} / 1 \mathrm{~T}$ pre-treatment for $48 \mathrm{~h}$; and lane $11,10 \mu \mathrm{mol} / 1$ $\mathrm{T}$ pre-treatment for $48 \mathrm{~h}$. (C) Effects of T on the concentration of MCP-1 and IL-6 in supernatants of 3T3-L1 adipocytes with or without LPS. Lane 1, controls; lane 2, $1 \mu \mathrm{g} / \mathrm{ml}$ LPS treated for $6 \mathrm{~h}$; lane 3, $10 \mu \mathrm{mol} / 1 \mathrm{~T}$ treated for $12 \mathrm{~h}$; and lane $4,10 \mu \mathrm{mol} / 1 \mathrm{~T}$ pre-treated $12 \mathrm{~h}$ with subsequent $1 \mu \mathrm{g} / \mathrm{ml} \mathrm{LPS}$ treatment for $6 \mathrm{~h}$. T, Testosterone; LPS, lipopolysaccharide; MCP-1, macrophage chemotactic protein-1; IL-6, interleukin-6.

sample was incubated overnight at $4^{\circ} \mathrm{C}$ without agitation. Subsequently, each well was washed five times using $200 \mu \mathrm{l}$ of $1 \mathrm{X}$ wash buffer. Diluted rabbit polyclonal NF- $\mathrm{KB}(\mathrm{p} 65)$ antibody (100 $\mu \mathrm{l}$; 06-418; 1:1000, EMD Millipore, Billerica, MA, USA) was added to each well, with the exception of blank wells. The treatments were incubated for $1 \mathrm{~h}$ at room temperature without agitation. Each well was washed five times using $200 \mu l$ of $1 \mathrm{X}$ wash buffer. Diluted goat anti-rabbit secondary antibody $(100 \mu \mathrm{l})$ was added to the wells, with the exception of the blank wells. Wells were incubated for $1 \mathrm{~h}$ at room temperature without agitation. Each well was washed five times using $200 \mu \mathrm{l}$ of $1 \mathrm{X}$ wash buffer. Developing solution $(100 \mu \mathrm{l})$ was added to each well. Wells were incubated for 15-45 min with gentle agitation. Stop solution (100 $\mu \mathrm{l})$ was added to each well and absorbance was measured at $450 \mathrm{~nm}$ using a Benchmark microplate reader, Model 680 (Bio-Rad Laboratories).

Electrophoretic mobility shift assay (EMSA). Cellular nuclear extracts were prepared using the Chemiluminescent EMSA kit according to the manufacturer's instructions (Viagene
Biotech, Tampa, FL, USA). Briefly, $6 \%$ polyacrylamide gel in $0.5 \%$ Tris/Borate/EDTA (TBE) (Double Helix) was prepared. The gel was placed in the electrophoresis unit (Double Helix), and the wells were flushed, such that the gel underwent pre-electrophoresis for 30-60 $\mathrm{min}$ at $100 \mathrm{~V}$. The bind reaction [containing: $12 \mu \mathrm{l}$ double-distilled water, 10X $4 \mu \mathrm{g}$ binding buffer, $1 \mu \mathrm{l}$ poly L-lysine, $1 \mu \mathrm{l}$ Poly (deoxyinosinicdeoxycytidylic) acid, $4 \mu \mathrm{g}$ cellular nuclear extracts and $2 \mu \mathrm{l}$ Detect Biotin-labeled DNA; all from Chemiluminescent EMSA kit] was incubated at room temperature for $20 \mathrm{~min}$. Six X loading buffer $(4 \mu \mathrm{l})$ was added, the wells were flushed and $10 \mu \mathrm{l}$ of each sampler was loaded onto the $4-6 \%$ polyacrylamide gel. The current was switched to $100 \mathrm{~V}$, and the samples underwent electrophoresis until the bromophenol blue dye had migrated approximately $2 / 3$ down the length of the gel. Electrophoretic transfer of the binding reaction to Nylon membrane (Shanghai-seok Optoelectronics Technology Co., Ltd., Shanghai, China) was conducted. Transfer was performed at $100 \mathrm{~V}$ for $45 \mathrm{~min}$. The membrane was placed on a dry paper towel with the bromophenol blue side up following the completion of the transfer. Cross-link transfer of DNA to the membrane was performed using a UV-light cross-linking instrument (Scientz 03-II; Ningbo Scientz Biotechnology Co., Ltd, Ningbo, China) equipped with $254 \mathrm{~nm}$ bulbs for 15 min. Finally the biotin-labelled DNA was detected by the Chemiluminescent EMSA kit; membranes were placed in a film cassette (Shanghai Fuji Medical Equipment Co., Ltd., Shanghai, China) and exposed to X-ray film (Premier Lab Supply, Port St. Lucie, FL, USA) for 2-5 min, then developed.

Western blot analysis. Whole cell lysates were prepared by lysing cells using a radioimmunoprecipitation assay lysis buffer with proteinase inhibitor phenylmethylsulfonyl fluoride (1 mM) and phosphatase inhibitor $\mathrm{NaF}(1 \mathrm{mM})$, which were obtained from Sigma-Aldrich. Equal amounts of protein fractions of the lysates with antibodies were resolved over sodium dodecyl sulphate-polyacrylamide gel electrophoresis and transferred to the polyvinylidene difluoride membrane (Immobilon-P; Millipore, Billerica, MA, USA). Proteins were detected using primary antibodies followed by horseradish peroxidase-conjugated secondary antibodies. Comparable loading of proteins on the gel was verified by re-probing the blots with an antibody specific for the reference gene, $\beta$-actin. Primary antibodies

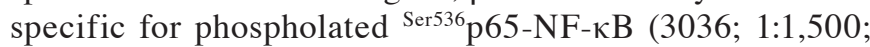
mouse monoclonal), total NF- $\mathrm{B}$ (3034; 1:2,000; polyclonal), phospholation ERK1/2 (9101; 1:2,000; polyclonal), total ERK1/2 (9102; 1:2,000; polyclonal), phospholated p38MAPK (5104; 1:2,000; monoclonal), total p38MAPK (9212; 1:3,000; polyclonal) and $\beta$-actin $(3700 ; 1: 3,000 ;$ monoclonal) were obtained from Cell Signaling Technology Inc. (Boston, MA, USA), and conjugated secondary antibodies were obtained from Santa Cruz Biotechnology, Inc. (Santa Cruz, CA, USA). Image J 1.38 image analysis software was used to analyze and quantify the relative expression of blots.

Reverse transcription-polymerase chain reaction (RT-PCR). Total RNA was extracted from $5 \times 10^{5}$ cells using a commercial kit (TRIzol Reagent, Invitrogen Life Technologies, Carlsbad, CA, USA) according to the manufacturer's instructions, and was spectrophotometrically quantified (Biomate 3, Thermo 
A

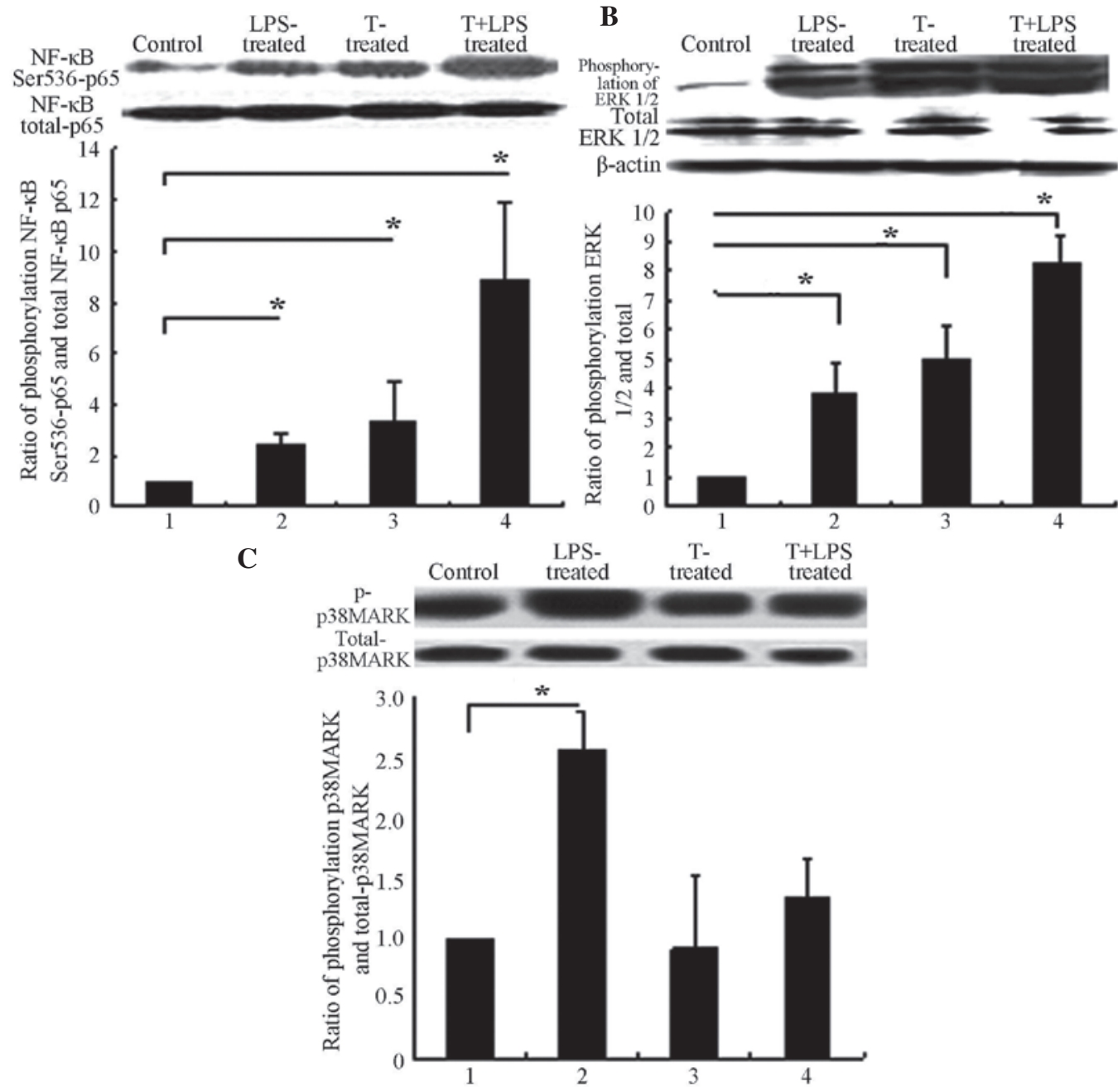

Figure 3. T promoted the phosphorylation of NF-kB subunit p65 and ERK1/2. 3T3-L1 adipocytes were treated with T alone or in combination with LPS $(1 \mu \mathrm{g} / \mathrm{ml})$, or control for $12 \mathrm{~h}$. Cell lysates were then prepared and subjected to sodium dodecyl sulphate polyacrylamide gel and western blot analysis. The protein phosphorylation was detected using a specific antibody. Images shown are representative immunoblots from $\geq 3$ independent experiments. (A) $\mathrm{T}$ promoted and enhanced LPS-induced phosphorylations of NF-kB submit p65. (B) T promoted and enhanced LPS-induced phosphorylations of ERK1/2. (C) T did not promote the phosphorylations of p38MAPK. (A), (B) and (C) Group 1, controls; group 2, $1 \mu \mathrm{g} / \mathrm{ml} \mathrm{LPS}$ treatment for $6 \mathrm{~h}$; group $3,10 \mu \mathrm{mol} / 1 \mathrm{~T}$ treatment for $12 \mathrm{~h}$ only; and group $4,10 \mu \mathrm{mol} / 1 \mathrm{~T}$ pre-treatment for $12 \mathrm{~h}$, with subsequent $1 \mu \mathrm{g} / \mathrm{ml} \mathrm{LPS}$ treatment for $6 \mathrm{~h}$. "P>0.05. T, Testosterone; LPS, lipopolysaccharide; NF-кB, nuclear factor-кB; p38-MAPK, p38 mitogen-activated protein kinase; ERK 1/2, extracellular signal-regulated kinase 1/2.

Electron Corp. Madison, WI, USA). Total RNA $(1 \mu \mathrm{g})$ was reverse transcribed using a high-capacity cDNA Archive kit (Applied Biosystems Life Technologies, Beijing, China) and random primers according to the manufacturer's instructions. In addition, $0.5 \mu \mathrm{g}$ total cDNA was used to quantify the levels of MCP-1 and IL- 6 cDNA through RT-PCR. $\beta$-actin cDNA was used as an endogenous control for final normalization.

RT-PCR was conducted using the following primers (Takara Bio, Inc., Dalian, China): Forward: 5'-CCACTTCACAAGTCGGAGGCTTA-3' and reverse: 5'-GCAAGTGCATCATCGTTGTTCATAC-3' for IL-6, forward: 5'-GCATCCACGTGTTGGCTCA-3' and reverse: 5'-CTCCAGCCTACTCATTGGGATCA-3' for MCP-1 and forward: 5'-CATCCGTAAAGACCTCTATGCCAAC-3' and reverse: 5'-ATGGAGCCACCGATCCACA-3' for $\beta$-actin.

Statistical analysis. All data are expressed as the mean \pm standard deviation. mRNA data were log-transformed prior to analysis. Statistical analysis software SPSS 15.0 (SPSS, Inc., Chicago, IL, USA) was used to perform two-way analysis of variance (ANOVA) on repeated measures in order to evaluate the effect of exercise (time). Differences between specific time points were determined using the Student-Newman-Keuls test. Student's t-test was used to determine any difference between the control and the carbohydrate trials at the end of the exercise. $\mathrm{P}<0.05$ was considered to indicate a statistically significant difference.

\section{Results}

Effects of testosterone on IL-6 and MCP-1 expression with or without LPS. Two-way ANOVA for supernatant IL-6 and MCP-1 concentrations in different treatment groups, suggested that testosterone increases the concentrations of IL-6 and MCP-1 in the supernatant, compared with that in blank controls. The concentration with the most marked promoting activity was $10 \mu \mathrm{mol} / 1$ testosterone for a period of $24 \mathrm{~h}$, and the differences were statistically significant $(\mathrm{P}<0.05$; Fig. 1A and B). The results also showed that with $10 \mu \mathrm{mol} / 1$ testosterone pre-treatment for $24 \mathrm{~h}$ and subsequent LPS-treatment 
A
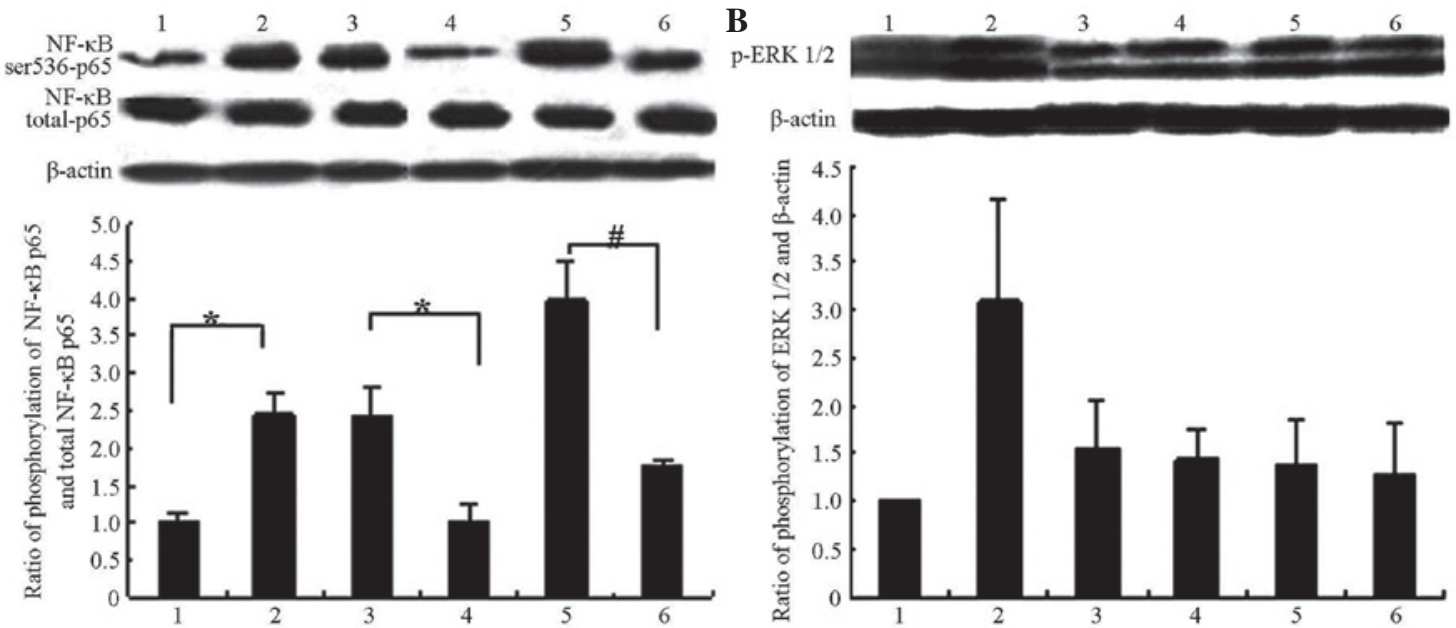

C

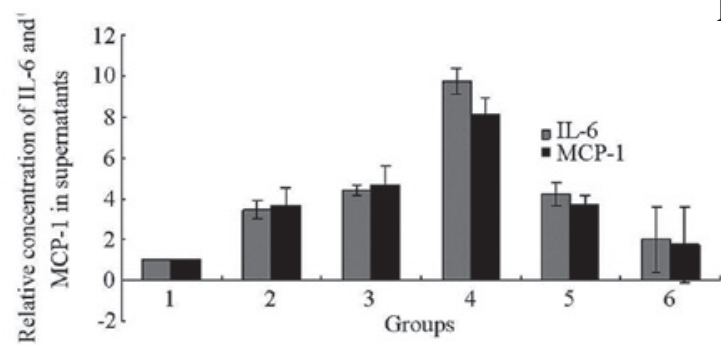

$\mathbf{E}$

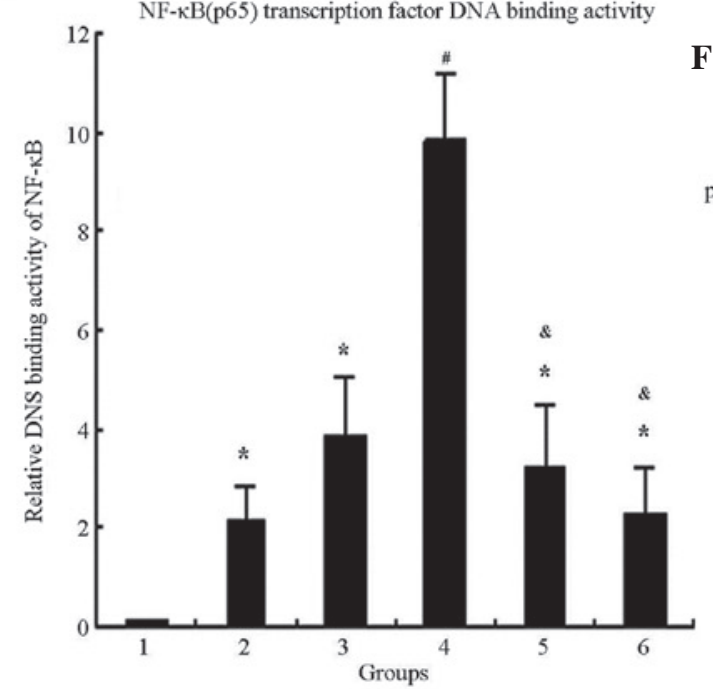

D

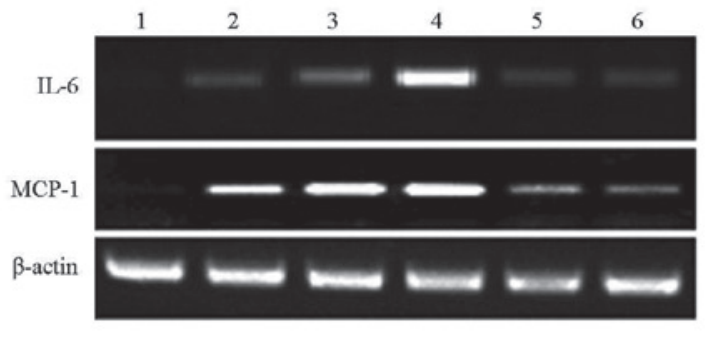

F $65 \mathrm{NF}-\mathrm{\kappa B} \rightarrow$

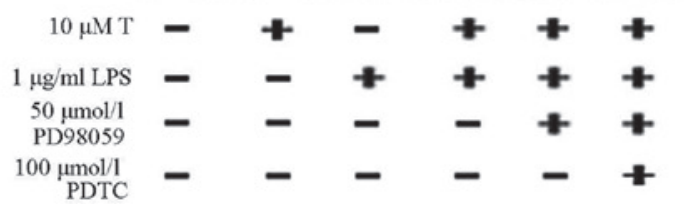

Figure 4. T promoted and enhanced the production of LPS-induced inflammatory factors, IL-6and MCP-1, via sequentially activating theERK1/2/NF-kB pathways . (A) Addition of the ERK1/2 inhibitor, PD98059, partially inhibited the activation of T on NF- $\mathrm{kB}$ (Ser536) p65. "P<0.05 and "P<0.01. Group 1, controls; group 2: $1 \mu \mathrm{g} / \mathrm{ml}$ LPS treatment for $6 \mathrm{~h}$; group 3, $10 \mu \mathrm{mol} / 1 \mathrm{~T}$ treatment for $12 \mathrm{~h}$ only; group $4,50 \mu \mathrm{mol} / 1 \mathrm{PD} 98059$ pre-treatment for $2 \mathrm{~h}$, then $10 \mu \mathrm{mol} / 1 \mathrm{~T}$ treatment for $12 \mathrm{~h}$; group $5,10 \mu \mathrm{mol} / 1 \mathrm{~T}$ pre-treatment for $12 \mathrm{~h}$, then $1 \mu \mathrm{g} / \mathrm{ml} \mathrm{LPS} \mathrm{treatment} \mathrm{for} 6 \mathrm{~h}$; and group $6,50 \mu \mathrm{mol} / 1$ PD $98059 \mathrm{pre}$-treatment for $2 \mathrm{~h}, 10 \mu \mathrm{mol} / 1$ $\mathrm{T}$ treatment for $12 \mathrm{~h}$, then $1 \mu \mathrm{g} / \mathrm{ml}$ LPS treatment for $6 \mathrm{~h}$. (B) Addition of NF- $\mathrm{kB}$ inhibitor PDTC did not inhibit the activation by T of ERK1/2. No significant difference was detected between groups 3, 4, 5 and 6 ( $P>0.05$ ). Group 1, controls; group 2, $1 \mu \mathrm{g} / \mathrm{ml}$ LPS treatment for $6 \mathrm{~h}$; group 3, $10 \mu \mathrm{mol} / 1 \mathrm{~T}$ treatment for $12 \mathrm{~h}$ only; group 4, $100 \mu \mathrm{mol} / 1$ PDTC pre-treatment for $2 \mathrm{~h}$, then $10 \mu \mathrm{mol} / 1 \mathrm{~T}$ treatment for $12 \mathrm{~h}$; group $5,10 \mu \mathrm{mol} / 1 \mathrm{~T}$ pre-treatment for $12 \mathrm{~h}$, then $1 \mu \mathrm{g} / \mathrm{ml}$ LPS treatment for $6 \mathrm{~h}$; and group $6,100 \mu \mathrm{mol} / 1$ PDTC pre-treatment for $2 \mathrm{~h}, 10 \mu \mathrm{mol} / 1 \mathrm{~T}$ treatment for $12 \mathrm{~h}$, then $1 \mu \mathrm{g} / \mathrm{ml} \mathrm{LPS} \mathrm{treatment} \mathrm{for} 6 \mathrm{~h}$. (C) Addition of PDTC (NF-kB inhibitor) or PD98059 (ERK1/2 inhibitor) partially decreased the concentrations of IL-6 and MCP-1 in supernatants. There was a signficant difference between group 4 and group 5, as well as between groups 4 and 6, groups 1 and 5 , and groups 1 and $6(\mathrm{P}<0.05)$. Group 1, controls; group 2, $10 \mu$ mol/1 testosterone treatment for $12 \mathrm{~h}$ only; group $3,1 \mu \mathrm{g} / \mathrm{ml} \mathrm{LPS} \mathrm{treatment} \mathrm{for} 6 \mathrm{~h}$; group $4,10 \mu \mathrm{mol} / 1 \mathrm{~T}$ pre-treatment for $12 \mathrm{~h}$, then $1 \mathrm{mg} / \mathrm{ml} \mathrm{LPS} \mathrm{treatment} \mathrm{for}$ $6 \mathrm{~h}$; group 5, $100 \mu \mathrm{mol} / 1$ PDTC pre-treatment for $2 \mathrm{~h}, 10 \mu \mathrm{mol} / 1 \mathrm{~T}$ treatment for $12 \mathrm{~h}$, then $1 \mu \mathrm{g} / \mathrm{ml} \mathrm{LPS} \mathrm{treatment} \mathrm{for} 6 \mathrm{~h}$; and group $6,50 \mu \mathrm{mol} / 1 \mathrm{PD} 98059$ pre-treatment for $2 \mathrm{~h}, 10 \mu \mathrm{mol} / 1 \mathrm{~T}$ pre-treatment for $12 \mathrm{~h}$, then $1 \mu \mathrm{g} / \mathrm{ml} \mathrm{LPS} \mathrm{treatment} \mathrm{for} 6 \mathrm{~h}$. (D) Addition of PDTC (NF-kB inhibitor) or PD98059 (ERK1/2 inhibitor) partially decreased the mRNA expression of IL-6 and MCP-1. Group 1, controls; group 2, $10 \mu \mathrm{mol} / \mathrm{l} \mathrm{T}$ treatment for $12 \mathrm{~h}$ only; group $3,1 \mu \mathrm{g} / \mathrm{ml} \mathrm{LPS}$ treatment for $6 \mathrm{~h}$; group $4,10 \mu \mathrm{mol} / 1 \mathrm{~T}$ pre-treatment for $12 \mathrm{~h}$, then $1 \mu \mathrm{g} / \mathrm{ml} \mathrm{LPS}$ treatment for $6 \mathrm{~h}$; group $5,100 \mu \mathrm{mol} / 1$ PDTC pre-treatment for $2 \mathrm{~h}, 10 \mu \mathrm{mol} / 1 \mathrm{~T}$ treatment for $12 \mathrm{~h}$, then $1 \mu \mathrm{g} / \mathrm{ml} \mathrm{LPS} \mathrm{treatment} \mathrm{for} 6 \mathrm{~h}$; and group $6,50 \mu \mathrm{mol} / 1$ PD $98059 \mathrm{pre}$-treatment for $2 \mathrm{~h}, 10 \mu \mathrm{mol} / 1 \mathrm{~T}$ pre-treatment for $12 \mathrm{~h}$, then $1 \mu \mathrm{g} / \mathrm{ml}$ LPS treatment for $6 \mathrm{~h}$. (E-F) Two methods were used to test whether or not T promotes LPS-induced NF- $\mathrm{BB}$ (p65) transcription factor DNA-binding activity in 3T3-L1 adipocytes. Group 1, controls; group 2, $10 \mu \mathrm{mol} / 1 \mathrm{~T}$ treatment for $12 \mathrm{~h}$ only; group 3, $1 \mu \mathrm{g} / \mathrm{ml} \mathrm{LPS}$ treatment for $6 \mathrm{~h}$; group 4, $10 \mu \mathrm{mol} / 1 \mathrm{~T}$ pre-treatment for $12 \mathrm{~h}$, then $1 \mu \mathrm{g} / \mathrm{ml}$ LPS treatment for $6 \mathrm{~h}$; group 5, $50 \mu \mathrm{mol} / 1$ PD 98059 pre-treatment for $2 \mathrm{~h}, 10 \mu \mathrm{mol} / 1 \mathrm{~T}$ pre-treatment for $12 \mathrm{~h}$, then $1 \mu \mathrm{g} / \mathrm{ml} \mathrm{LPS}$ treatment for $6 \mathrm{~h}$; and group $6,100 \mu \mathrm{mol} / 1$ PDTC pre-treatment for $2 \mathrm{~h}, 10 \mu \mathrm{mol} / 1 \mathrm{~T}$ treatment for $12 \mathrm{~h}$, then $1 \mu \mathrm{g} / \mathrm{ml}$ LPS treatment for $6 \mathrm{~h}$. (E) Enzyme-linked immunosorbent assay for detecting NF- $\mathrm{kB}$ (p65) transcription factor DNA binding activity. (F) Electrophoretic mobility shift assay for detecting NF- $\mathrm{\kappa B}$ (p65) transcription factor DNA binding activity. ${ }^{*} \mathrm{P}<0.05$ compared with controls, ${ }^{~} \mathrm{P}<0.01$ compared with controls and ${ }^{\text {\& }} \mathrm{P}<0.05$ compared with group 4 . $\mathrm{T}$,

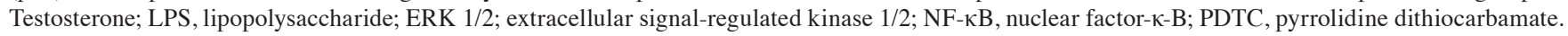




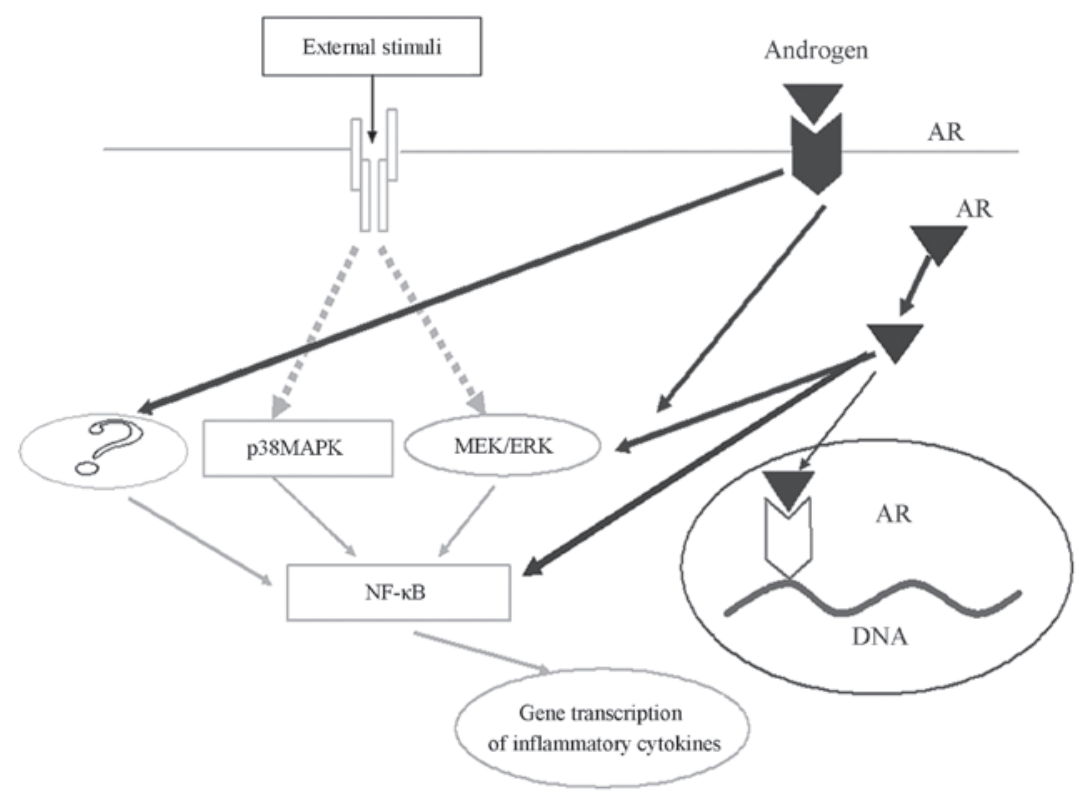

Figure 5. Testosterone promotion of IL-6 and MCP-1 is partially dependent on the ERK1/2/NF- $\mathrm{KB}$ pathway, however, testosterone may act on other signalling pathways promote inflammatory factors, which also facilitates the generation of inflammatory factors. IL-6, Interleukin-6; MCP-1, macrophage chemotactic

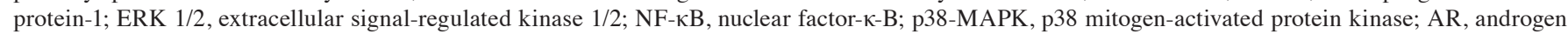
receptor; ?, molecules which remain unknown.

for $6 \mathrm{~h}$, the expression of IL-6 and MCP-1 in 3T3-L1 adipocytes was greater than that in the LPS-only group or the testosterone-only group (Fig. 1C and D). Testosterone, used as pre-treatment in 3T3-L1 adipocytes, dramatically augmented the LPS-stimulated production of IL-6 and MCP-1 in the supernatants $(\mathrm{P}<0.05)$. Testosterone induced IL-6 and MCP-1 expression, and also enhanced LPS-induced IL-6 and MCP-1 expression in 3T3-L1 adipocytes, although not in a time- or dose-dependent manner.

Based on these results, $10 \mu \mathrm{mol} / 1$ testosterone treatment for $24 \mathrm{~h}$ was subsequently used to analyse the effects of testosterone on the protein expression of IL-6 and MCP-1 in supernatants of 3T3-L1 adipocytes, with or without LPS treatment.

Testosterone increases LPS-induced expression of inflammatory factors (IL-6, MCP-1) mRNA expression in 3T3-L1 adipocytes. The 3T3-L1 adipocytes treated with $10 \mu \mathrm{mol} / \mathrm{l}$ testosterone for $12 \mathrm{~h}$ exhibited significantly higher IL-6 and MCP-1 mRNA than other groups treated with testosterone only for different time periods, at different doses $(\mathrm{P}<0.05$; Fig. 2A). The 3T3-L1 adipocytes pre-treated with $10 \mu \mathrm{mol} / 1$ testosterone for $12 \mathrm{~h}$, with the addition of LPS for $6 \mathrm{~h}$, exhibited significantly higher concentrations of IL-6 and MCP-1 mRNA compared with any other group ( $\mathrm{P}<0.05$; Fig. 2B). In subsequent experiments, $10 \mu \mathrm{mol} / 1$ testosterone for $12 \mathrm{~h}$ was used to detect the mRNA expression of IL-6 and MCP-1 (Fig. 2C).

Testosterone activates the ERK1/2 and NF- $\kappa B$ signalling pathways in 3T3-L1 adipocytes with or without LPS treatment. Testosterone promoted the phosphorylation of $\mathrm{NF}-\kappa \mathrm{B}$ Ser536-p65. Specifically, testosterone activated NF- $\kappa$ B, at a concentration of $10 \mu \mathrm{mol} / 1$ testosterone for $12 \mathrm{~h}$, as determined in preliminary experiments (data not shown). Therefore,
$10 \mu \mathrm{mol} / 1$ testosterone for $12 \mathrm{~h}$ was used in subsequent experiments. Testosterone promoted and enhanced LPS-induced phosphorylation of NF- $\mathrm{B}$ p 65 (Fig. 3A) and also promoted and enhanced LPS-induced phosphorylation of ERK1/2 (Fig. 3B). However, testosterone did not promote the phosphorylation of p38MAPK (Fig. 3C).

Testosterone promotes and enhances LPS-induced inflammatory factors, IL- 6 and MCP-1, via sequentially activating the ERK1/2/NF- $\kappa B$ pathways. Adding the ERK1/2 inhibitor, PD98059, partially inhibited the activation by testosterone of

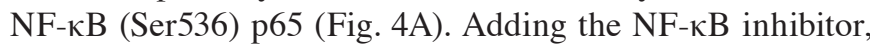
pyrrolidine dithiocarbamate (PDTC), however, did not alter the activation by testosterone of ERK1/2 (Fig. 4B). PDTC and PD98059 partially blocked the testosterone-mediated downregulation of IL-6 and MCP-1 expression in 3T3-L1 adipocytes (Fig. 4C and D).

Without LPS treatment, levels of IL- 6 and MCP-1 in the supernatant were the highest following $10 \mu \mathrm{mol} / 1$ testosterone treatment for $24 \mathrm{~h}$. In the LPS-stimulated state, IL- 6 and MCP-1 in the supernatant were the highest following $10 \mu \mathrm{mol} / 1$ pre-treatment for $24 \mathrm{~h}$ with subsequent LPS treatment for $6 \mathrm{~h}$. Furthermore, PDTC or PD98059 were also added in order, to observe IL-6 and MCP-1 in the supernatant.

PDTC and PD98059 partially blocked the testosterone-mediated activation of $\mathrm{NF}-\kappa \mathrm{B}$ transcription factor DNA-binding activity in 3T3-L1 adipocytes by 74 and $53 \%$, respectively (Fig. 4E and F).

\section{Discussion}

Recent studies have demonstrated that patients with PCOS exhibit metabolic inflammation in the form of increases in peripheral white blood cell and neutrophil counts, and elevation in a number of inflammatory factors in the serum, such 
as C-reactive protein, TNF- $\alpha$, IL-6, IL-18 and MCP-1. The levels of inflammatory factors in patients with PCOS patients are higher than those in control groups, following adjustment for factors, such as age and body mass index (27). Thus, metabolic inflammation may be a fundamental characteristic of PCOS, although the mechanism underlying this effect remains unclear. A number of studies have suggested that an increase in the levels of inflammatory cytokines, such as IL-6 and MCP-1, inhibits the activity of insulin receptor tyrosine kinase, which may result in the development of metabolic diseases, including PCOS $(9,28)$. White adipocytes were recently shown to be associated with inflammation (29). During pathogenic stimulation, an inflammation signal transduction cascade was activated in adipocytes, and the levels of inflammatory cytokines, such as TNF, MCP-1 and IL-6, increased. As immune cells, adipocytes activate complement, resulting in increases in the levels of inflammatory factors and chemokines. Adipocytes are target cells of androgens and are also classical endocrine cells. Thus, mature 3T3-L1 adipocytes were used in the present study in order to investigate the mechanisms underlying metabolic inflammation, and to clarify the association between the hyperandrogenitic environment and metabolic disease.

In the present study, in contrast to the controls, testosterone promoted the production of IL- 6 and MCP-1. In the LPS-stimulated state, testosterone-pre-treatment increased LPS-stimulated IL-6 and MCP-1 expression. Thus, it was inferred that testosterone directly promotes IL-6 and MCP-1 expression, as well as the response of adipocytes to external stimuli, thereby producing higher levels of the inflammatory cytokines, IL-6, MCP-1. These effects were not simply additive, testosterone significantly enhanced the effects of LPS-induced inflammation factors, as determined by further statistical analysis.

Signalling pathway activation may be involved in the pathogenesis of metabolic inflammation in PCOS. The generation of inflammatory factors depends primarily on the activation of the inflammatory signalling pathway (30).

Clinical studies have confirmed that ERK1/2 and $\mathrm{NF}-\kappa \mathrm{B}$ activation is higher in patients with PCOS than in healthy subjects $(31,32)$. p38-MAPK, NF- $\mathrm{B}$ and ERK1/2 are important factors, associated with the proliferation of numerous types of cells, including prostatic cells and fibroblasts, which are mediated by androgens and are also closely associated with the inflammatory signalling pathway (33-35). Testosterone activates inflammatory signalling pathways in adipocytes, while promoting the generation of inflammatory cytokines (Fig. 5). To the best of our knowledge, there have been no reports relevant to these findings. The present study demonstrated that with or without LPS treatment, testosterone activates NF- $\kappa \mathrm{B}$ and ERK1/2. Furthermore, it was shown that testosterone activates ERK1/2 and $\mathrm{NF}-\kappa \mathrm{B}$, thus producing higher concentrations of inflammatory cytokines in adipocytes. However, PD98059, an ERK1/2 antagonist, partially (53\%) blocks the NF- $\mathrm{BB}$ DNA-binding activity of testosterone (IL-6 and MCP-1 were partially reduced, 70 and $44 \%$, respecitively). Thus, the results suggest that testosterone may also activate other intracellular signal transduction pathways, thereby preventing complete PD98059-induced blocking of the effects of testosterone. PDTC partially blocked the NF- $\mathrm{BB}$ DNA-binding activity of testosterone (74\%), and this capability was greater than that of PD98059 (53\%; IL-6 and MCP-1 were partially reduced, 68 and $41 \%$, respectively). Thus, NF- $\kappa \mathrm{B}$ may be the primary regulator of IL- 6 and MCP-1, and may be a downstream signalling molecules in the ERK1/2 pathway, which requires further investigation.

A number of clinical studies have demonstrated that PCOS patients are in a state of chronic metabolic inflammation. The present study hypothesised that PCOS patients are highly sensitive to external stimuli compared with normal subjects, probably because of hyperandrogemia, which results in the increased production of inflammatory factors by other external stimuli.

The present study has certain limitations. IL- 6 and MCP-1 were investigated. However, other inflammatory factors require further exploration. In addition, the present study was conducted in vitro due to the complexities of pathways in vivo. Thus, further in vivo studies are required.

In conclusion, testosterone promotes IL-6 and MCP-1, and this effect is partially dependent on the ERK1/2/NF- $\kappa \mathrm{B}$ pathway. Testosterone, however, when promoting inflammatory factors, may be dependent on other signalling pathways that also facilitate the generation of inflammatory factors (Fig. 5).

\section{Acknowledgements}

This study was supported by the National Natural Science Foundation of China (grant no.30973186) and the Youth Natural Science Foundation of Shanghai, (grant no. 12ZR1441400).

\section{References}

1. Legro RS, Kunselman AR, Dodson WC and Dunaif A: Prevalence and predictors of risk for type 2 diabetes mellitus and impaired glucose tolerance in polycystic ovary syndrome: a prospective, controlled study in 254 affected women. J Clin Endocrinol Metab 84: 165-169, 1999.

2. Hu G, Qiao Q, Tuomilehto J, Balkau B, Borch-Johnsen K and Pyorala K; DECODE Study Group: Prevelence of the metabolic syndrome and its relation to all-cause and cardiovascular mortality in nondiabetic European men and women. Arch Intern Med 164: 1066-1076, 2004

3. Boura-Halfon S and Zick Y: Phosphorylation of IRS proteins, insulin action, and insulin resistance. Am J Physiol Endocrinol Metab 296: E581-E591, 2009.

4. Coviello AD, Legro RS and Dunaif A: Adolescent girls with polycystic ovary syndrome have an increased risk of the metabolic syndrome associated with increasing androgen levels independent of obesity and insulin resistance. J Clin Endocrinol Metab 91: 492-497, 2006.

5. Banaszewska B, Pawelczyk L, Spaczynski RZ, Dziura J and Duleba AJ: Effects of simvastatin and oral contraceptive agent on polycystic ovary syndrome: prospective, randomized, crossover trial. J Clin Endocrinol Metab 92: 456-461, 2007.

6. Ibáñez L, Jaramillo AM, Ferrer A and de Zegher F: High neutrophil count in girls and women with hyperinsulinaemic hyperandrogenism: normalization with metformin and flutamide overcomes the aggravation by oral contraception. Hum Reprod 20: 2457-2462, 2005.

7. González F, Rote NS, Minium J and Kirwan JP: In vitro evidence that hyperglycemia stimulates tumor necrosis factor-alpha release in obese women with polycystic ovary syndrome. J Endocrinol 188: 521-529, 2006.

8. Tataranni PA and Ortega E: A burning question: does an adipokine-induced activation of the immune system mediate the effect of overnutrition on type 2 diabetes? Diabetes 54: 917-927, 2005.

9. Lumeng CN and Saltiel AR: Inflammatory links between obesity and metabolic disease. J Clin Invest 121: 2111-2117, 2011.

10. Nicklas BJ, Ambrosius W, Messier SP, et al: Diet-induced weight loss, exercise, and chronic inflammation in older, obese adults: a randomized controlled clinical trial. Am J Clin Nutr 79: 544-551, 2004. 
11. Mohamed-Ali V, Goodrick S, Rawesh A, et al: Subcutaneous adipose tissue releases interleukin-6, but not tumour necrosis factor-alpha, in vivo. J Clin Endocrinol Metab 82: 4196-4200, 1997.

12. Lagathu C, Bastard JP, Auclair M, Maachi M, Capeau J and Caron M: Chronic interleukin (IL-6) treatment increased IL-6 secretion and induced insulin resistance in adipocyte: prevetion by rosigilitazone. Biochem Biophys Res Commun 311: 372-379, 2003.

13. Homaidan FR, Chakroun I and El-Sabban ME: Regulation of nuclear factor-kappaB in intestinal epithelial cells in a cell model inflammation. Mediators Inflamm 12: 277-283, 2003.

14. Shoelson SE, Lee J and Goldfine AB: Inflammation and insulin resistance. Clin Invest 116: 1793-1801, 2006.

15. Ognjanovic S, Jacobs DR, Steinberger J, Moran A and Sinako AR Relation of chemokines to BMI and insulin resistance at ages 18-21. Int J Obes (Lond) 37: 420-423, 2013.

16. Gerhardt CC, Romero IA, Cancello R, Camoin L and Strosberg AD: Chemokines control fat accumulation and leptin secretion by cultured human adipocytes. Mol Cell Endocrinol 175: 81-92, 2001

17. Takahashi K, Mizuarai S, Araki H, et al: Adipocity elevates plasma MCP-1 levels leading to the increased CD11b-positive monocytes in mice. J Biol Chem 278: 46654-46660, 2003.

18. Kershaw EE and Flier JS: Adipose tissue as an endocrine organ. J Clin Endocrinol Metab 89: 2548-2556, 2004.

19. Hsiung SC, Tamir H, Franke TF and Liu KP: Roles of extracellular signal-regulated kinase and Akt signaling in coordinating nuclear transcription factor-kappaB-dependent cell survival after serotonin 1A receptor activation. J Neurochem 95: 1653-1666, 2005.

20. Kaidashev IP: Activation of NF- $\kappa \mathrm{B}$ under metabolic syndrome. Internationl J Physiol Pathophysiol 3: 287-297, 2012.

21. Suganami T, Tanimoto-Koyama K, Nishida J, et al: Role of the toll-like receptor 4/NF-kappaB pathway in saturated fatty acid-induced inflammatory changes in the interaction between adipocytes and macrophages. Arterioscler Thromb Vasc Biol 27: 84-91, 2007.

22. Kovacheva EL, Hikim AP, Shen R, Sinha I and Sinha-Hikim I: Testosterone supplementation reverses sarcopenia in aging through regulation of myostatin, c-Jun NH2-terminal kinase, notch, and Akt signaling pathways. Endocrinology 151: 628-638, 2010.

23. Sun HZ, Yang TW, Zang WJ and Wu SF: Dehydroepiandrosterone-induced proliferation of prostatic epithelial cell is mediated by NFKB via PI3K/AKT signaling pathway. J Endocrinol 204: 311-318, 2010
24. Wu Y, Bauman WA, Blitzer RD and Cardozo C: Testosteroneinduced hypertrophy of L6 myoblasts is dependent upon Erk and mTOR. Biochem Biophys Res Commun 400: 679-683, 2010.

25. Yamamoto Y, Yoshimasa Y, Koh M, et al: Constitutively active mitogen-activated protein kinase kinase increases GLUT1 expression and recruits both GLUT1 and GLUT4 at the cell surface in 3T3-L1 adipocytes. Diabetes 49: 332-339, 2000.

26. Yin J, Zuberi A, Gao Z, Liu D, Liu Z and Ye J: Shilianhua extract inhibits GSK-3beta and promotes glucose metabolism. Am J Physiol Endocrinol Metab 296: E1275-E1280, 2009.

27. Benson S, Janssen OE, Hahn S, et al: Obesity, depression, and chronic low-grade inflammation in women with polycystic ovary syndrome. Brain Behav Immun 22: 177-184, 2008.

28. Marino JS, Iler J,Dowling AR, et al: Adipocyte dysfunction in a mouse model of polycystic ovary syndrome (PCOS): evidence of adipocyte hypertrophy and tissue-specific inflammation. PLoS One 7: e48643, 2012.

29. Greenberg AS and Obin MS: Obesity and the role of adipose tissue in inflammation and metabolism. Am J Clin Nutr 83 461S-465S, 2006.

30. Lei Y, Zhang Y, Cao Y, et al: Up-regulation of bradykinin receptors in rat bronchi via I kappa B kinase-mediated inflammatory signaling pathway. Eur J Pharmacol 634: 149-161, 2010.

31. Corbould A, Zhao H, Mirzoeva S, Aird F and Dunaif A: Enhanced mitogenic signaling in skeletal muscle of women with polycystic ovary syndrome. Diabetes 55: 751-759, 2006.

32. González F, Rote NS, Minium J and Kirwan JP: Increased activation of nuclear factor kappaB triggers inflammation and insulin resistance in polycystic ovary syndrome. J Clin Endocrinol Metab 91: 1508-1512, 2006.

33. Yeung YT, Bryce NS, Adams S, et al: p38 MAPK inhibitors attenuate pro-inflammatory cytokine production and the invasiveness of human U251 glioblastoma cells. J Neurooncol 109: 35-44, 2012.

34. Tan BK, Adya R, Chen J, et al: Metformin decreases angiogenesis via NF-kappaB and Erk1/2/Erk5 pathways by increasing the antiangiogenic thrombospondin-1. Cardiovasc Res 83: 566-574, 2009.

35. González F, Nair KS, Daniels JK, Basal E and Schimke JM: Hyperandrogenism sensitizes mononuclear cells to promote glucose-induced inflammation in lean reproductive-age women. Am J Physiol Endocrinol Metab 302: E297-E306, 2012. 